\title{
The Strategies for Educational Reform of Advertising in Colleges and Universities Under the Development of New Media
}

\author{
Jiao Lin \\ Xiamen University Tan Kah Kee College \\ Zhangzhou, China
}

\author{
Jing $\mathrm{Wu}^{*}$ \\ Xiamen University Tan Kah Kee College \\ Zhangzhou, China \\ *Corresponding Author
}

\begin{abstract}
With the continuous development of new media, the "global village" features proposed by McLuhan have become more and more prominent; the development of technologies such as mobile internet, VR and AR has enabled the media to achieve further "extension" of many human senses. A variety of new forms and new features in the advertising industry has appeared. Webcast and web celebrities are now popular, short videos and we media have become new communication arenas for advertisers. This media ecological background has put forward new requirements for the cultivation of professional talents in colleges and universities. Starting from the analysis of characteristics of new media development trend, this paper analyzes the core problems existing in current advertising education in colleges and universities, and discusses the reform strategies for advertising education in colleges and universities: The schools should base on their own professional characteristics, reshape the concept of talent cultivation with new media characteristics, establish the curriculum system with the courses about classic theories of communication and advertising as the foundation, new media hotspot courses as the core and platformbased courses as the extension; and conduct in-depth cooperation with enterprises and other institutions to cultivate industryadapted composite advertising talents.
\end{abstract}

Keywords—new media; advertising; education reform; strategy

\section{INTRODUCTION}

Media theorist Marshall McLuhan proposed several important media theories in the 20th century, among which the "global village" theory predicted an important development trend of human. The concept of "global village" was coined by McLuhan in the "Report on the Understanding of New Media" (1960, p. 129) in the 1960 s, arguing that with the development of electronic media, the earth would gradually turn into a "village", and human would eventually return to live in a tribal "global village". ${ }^{1}$ The theory of "medium is the extension of the human body" indicates that all media is just an extension of certain organs or senses of human beings. This has defined the important role of the media in people's life. Many years ago, the emergence of the Internet indicated that the "global village" was realized. Nowadays, with the emergence of new economic forms, new technologies and new media, the characteristics of the "global village" have become more and more prominent. Cross-circle communication and cross-border communication are easier to achieve. The media is more diversified; and the media, as an extension of the human body, has further extended the human senses with the development of new media such as mobile internet, VR and AR.

Under the background of the emergence of new media technologies and media terminals, new forms and new features of advertisements have appeared successively and changed rapidly. Webcast and web celebrities are now popular, and new purchase scenarios such as video out have attracted consumers' attention. Short videos and we media have become new communication arenas for advertisers. This media ecological background has put forward new requirements and new challenges for the training of college advertising professionals. Therefore, this thesis has firstly analyzed the characteristics of new media development, then analyzed the core problems existing in the current college advertising education in China, and finally proposed the reform strategies of college advertising education under the development of new media.

\section{ANALYSIS OF THE STATUS QUO AND TREND CHARACTERISTICS OF NEW MEDIA DEVELOPMENT}

\section{A. Overall, New Media Terminals Are Characterized by Intelligence, Diversity and Innovation}

With the advancement of digital technology and artificial intelligence, the development of Internet of Things, VR (Virtual Reality) and AR has accelerated, and new media terminals have been more and more intelligent and diverse, bringing more interactive experiences to consumers. And human-computer interaction has been more and more used in people's life and work. For example, the smart speaker named Classmate Xiao Ai launched by MI Company and the TmallGenie launched by Alibaba in 2017 are both dominant products in the smart speaker market. In addition, the use of new media terminals in the vertical industries has led to the birth of new media terminals, such as the electronic whiteboard in the education industry and the topical lipstick machine in the beauty field. 


\section{B. New Media Users Acquire Information in Daily Living Scenes with High Frequency and No Boundaries}

According to the 2017 Report on the Trends of New Media in China, nearly $60 \%$ of users choose to look through news and information on their mobile phones at home, and about $30 \%$ of users choose to look through information while they are going out such as when on the bus. ${ }^{2}$ It can be seen that obtaining information through mobile phones has become the main means for users to spend their fragmentary time. The scenes in which users obtain information are mainly daily living scenes, and the acquisition of information usually happens in the fragmentary time in people's life and work, the frequency of which is high.

\section{Mobile Media Users and Mobile Media Products (Mobile Games, Mobile APPs) Have Long Been Increasing}

According to the economic and operational data of the communication industry released by the Ministry of Industry and Information Technology in August 2018, from January to August 2018, China's telecom business revenue increased by $5.2 \%$ year-on-year. The proportion of $4 \mathrm{G}$ users has been more than a half, and the total number of users using mobile phones to access the Internet has reached 1.004 billion, achieving a historical peak. Monthly Internet access flow per household is nearly $800 \mathrm{M}$, and mobile Internet flow accounts for nearly $90 \%$. ${ }^{3}$ It can be seen that mobile media users are increasing rapidly, and mobile phones have become one of the main tools for users to access the Internet. At the same time, mobile games and apps have proliferated. According to the 42nd "Statistical Report on the Development of China's Internet Network" released by the China Internet Network Information Center on August 20, 2018, in the first half of 2018, the number of mobile game users in China was 458.33 million, an increase of 51.23 million compared with that of the end of 2017. And the mobile game players in the first half of 2018 have accounted for $58.2 \%$ of the total mobile Internet users. ${ }^{4}$

\section{Short Videos Have Started to Develop Rapidly}

The data shows that the number of online video users in China in the first half of 2018 reached 609.06 million, an increase of 30.14 million compared with that of the end of 2017 , accounting for $76.0 \%$ of the total Internet users. In the first half of 2018, the number of mobile video users in China was 577.86 million, an increase of 29.29 million compared with that of the end of 2017 , accounting for $73.4 \%$ of the total mobile Internet users. ${ }^{5}$ Short video as the main effective tool to attract users' attention in their fragmentary time, has entered the rapid development stage.

\section{E. Social Media Has Become a Main Battleground for the Brands to Compete with Each Other in Advertising}

Users of social media such as Weibo and WeChat are highly active, and social media has become a platform for consumers to exchange opinions and share information. Social media advertisements have emerged with the development of social media. All the advertisements based on social relationships and aimed at social media users can be called social media ads. ${ }^{6}$ As a new type of advertising and communication, social media advertising is favored by advertisers for its low cost and high communication efficiency.

In summary, the changes in the terminal hardware, user behavior, contents and forms, etc. of new media and the rapid development of new media have greatly affected the advertising methods and advertising industry. Future advertisements show a tendency to be recessive, purposeoriented, artistic, multimedia-disseminated, topical, and a tendency to change from advertising to just aiming at some certain group of people. ${ }^{7}$ In this context, the original model of advertising education in colleges and universities in China cannot fully adapt to the rapid development of media environment. Colleges and universities should conduct selfexamination in comparison with new changes in the media and advertising, dynamically adjust their ideas and specific implementation methods, and cultivate the advertising talents in line with the requirements in the new media era, so as to comply with the changes of times.

\section{The PROBLEMS IN THE PROFESSIONAL EDUCATION OF ADVERTISING}

\section{A. The Goal of Talent Training Is Not in Line with the Development Demand of New Media}

At present, the objectives of training advertising professionals of colleges and universities in China are mainly to cultivate the professionals who master the comprehensive capabilities of advertising planning, advertising creativity, advertising design, brand planning, media strategy, public relations, advertising copywriting, audiovisual advertising production, and advertising management. Only the training objectives of a few colleges and universities have reflected the development status and trends of new media. For example, a university has clearly pointed out that it is suitable for cultivating high-level $\mathrm{AE}$ talents that adapt to the new media communication environment. However, this description of talent training objectives is only applicable for this university itself.

\section{B. Course Construction Does Not Reflect the Hot Spots in New Media's Development}

Based on the above-mentioned training objectives, the undergraduate courses in advertising are mainly divided into three categories: first, the basic theory courses, such as the introduction to communication, the introduction to advertising, the history of Chinese and foreign communication, advertising psychology, branding, advertising history, public relations, etc.; second, the advertising practical, operational courses, such as advertising planning, media planning, market research, advertising copywriting, advertising photography, advertising graphic design, computer advertising production, etc.; third, innovative courses, such as a small number of newly opened courses including event marketing, integrated marketing communications, new media advertising and media convergence. Overall, the curriculum structure is still constructed on the basis of the advertising mode formed in the traditional media environment, and big data marketing, mobile advertising, virtual reality advertising, new media installation advertising and other new contents have not yet been offered as 
key courses, which makes the curriculum structure unable to meet the requirements for talents' new media abilities of the current industry.

\section{Overcorrection of "Attaching Importance to Theories and Taking Little Account of Practice"}

In recent years, some colleges and universities have vigorously advocated improving the practical and operational abilities of advertising majors, from "attaching importance to theories and taking little account of practice" to "improving the students' hands-on practical ability". Many of them have "overcorrected" the advertising majors. They have paid too much attention to the cultivation of students' specific skills such as advertising script creation, advertising shooting, graphic design and copywriting, and have neglected students' accumulation of theories of communication and advertising, leading to serious "imbalance in abilities" of students. Students usually have strong operational ability and weak theoretical thinking ability, and colleges and universities have lacked training in talent integration ability, which will seriously affect the long-term development of advertising talents in the fields of media, advertising and branding.

\section{The Linkage with the Advertising Companies Is Not Deep Enough}

Advertising majors have traditionally interacted with the industry by setting up an internship platform or base, inviting industry experts to give lectures or carry out short-term training, and recommending outstanding students to conduct internships in enterprises. Through these ways, colleges and universities are trying to close the distance between school education and corporate practice, and improve students' practical ability, so as to train the creative talents who can meet the actual needs of the market. In fact, the practice base can only conduct "postevent" inspection of the teaching effect, and does not have the function of forward-looking guidance. Experts can provide lectures or training, which can inspire students or give them a small amount of knowledge and experience, but cannot contribute to their construction of own knowledge systems in the daily learning process. Lectures or short-term training can not provide sustainable potential energy for students, and the learning effect is limited. Overall, the current linkage between advertising education and advertising practice is not deep enough.

\section{The Reform Strategies of COllege AdVertising EDUCATION UNDER THE DEVELOPMENT OF NEW MEDIA}

Based on the above analysis, this paper starts from the status quo and trend characteristics of new media development, combines the main problems in college advertising education, and tries to propose the directional strategies for advertising education reform from three aspects: education goal orientation, curriculum system construction and school-industry interaction.

\section{A. Education Goal Orientation Strategy}

1) Based on the characteristics of the school's own advertising major: The new media is developing and changing rapidly. When adapting to the development trend of the industry, colleges and universities should not forget to protect the school-running characteristics of their own advertising majors. On this basis, they should make educational reforms and innovations to continually strengthen the core competitiveness of their own majors.

2) Determine talent training standards according to the development trend of new media: Change from training advertising professionals for the main advertising companies and media to cultivating the comprehensive advertising composite talents who master the advertising, communication theories, master professional skills such as the operation of the entire media advertising process, application of new media technology and theory, mobile advertising planning production, short video shooting production, and social media advertising planning and creativity, and have content thinking, product thinking and operational thinking.

\section{B. Curriculum System Construction Strategy}

1) Taking courses about classical communication and advertising theories as the foundation of the curriculum system: Although the content and form of advertising have undergone profound changes due to the development of new media and new technologies, the classical theories in communication and advertising are the basic knowledge for students to understand the phenomenon of media and advertising, analyze the laws behind them, and use the laws to achieve the purpose of communication. Therefore, the basic training role of the classical academic theories of communication and advertising should be emphasized in advertising education, and the classical theories should be treated as the "foundation" of advertising talents' knowledge systems.

2) Developing and offering innovative courses according to the hot spots in new media development: Taking the current status and trends of new media development as the starting point, colleges and universities should combine new media research hot spots with original advertising courses to develop new media advertising courses, such as new media technologies and applications, mobile internet media (mobile media) advertising, social media advertising, Internet community operations, game advertising, new media product operations, new media brand communications, we media operations, etc. In this way, the professional course system of advertising can be perfected and more adaptable to new media. At the same time, the course assessment method should be innovated, with the kpi way closer to the market applied to evaluate students' performance in various courses.

3) Strengthening educational practice by offering laboratory, innovative and entrepreneurial courses: Offer new media laboratory, innovative and entrepreneurial courses, and establish a practical platform for students. For example, build a new media advertising frontier laboratory, guide students to develop new media advertising medium, advertising devices and new forms of advertising, cultivate students' creativity in new media development, and make them understand the future 
development trend of media and advertising. And construct the advertising course system jointly with the theoretical foundation courses and the hot spot innovative courses, as shown in "Fig. 1".

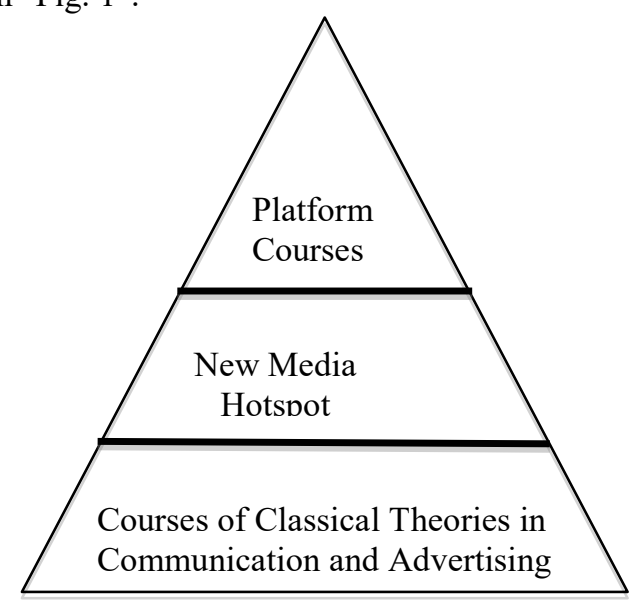

Fig. 1. The advertising course system jointly with the theoretical foundation courses and the hot spot innovative courses.

\section{Academia-industry Interaction Strategy}

1) Planning and implementing the college-enterprise joint training mode: Universities and enterprises, new media institutions should cooperate with each other and jointly cultivate the advertising professional compound talents that the market really needs by making use of the advantages of advertising disciplines of colleges and universities and basing on the actual demands for talents of the institutions. As for the specific implementation methods, universities and enterprises or new media institutions can jointly develop and teach relevant courses, and enterprises or institutions can provide scholarships and internship opportunities for students as incentives. After graduation, outstanding students can go to cooperative institutions for employment, and schools and enterprises should jointly develop and implement the talent training model.

2) Creating an educational practical model with the "trinity" of corporate proposition, competition project and course assessment: In view of the reality of "what students have learned is not useful for their work", on the one hand, the advertising task can be assigned and published by the cooperative enterprise for students before the course is started, and the teacher uses the published proposition as the course assessment content. At the end of the course, both the teacher and the enterprise will jointly evaluate the learning results of students. For the excellent programs, the enterprise can directly purchase them or cooperate with the designers of the programs. On the other hand, the students can participate in the innovation and entrepreneurship competition with their works which are completed course assessment tasks in the form of enterprise propositions, actively promoting the conversion of working results and the expansion of project influence.

\section{CONCLUSION}

At present, the development of new media has presented the following characteristics: The media terminals have become more intelligent, diversified and innovative; Information acquisition of users happens in more living scenes; Mobile media users and mobile media products have been increasing for a long term; Social media has become a main battleground for the brands to conduct fierce advertising competitions; Short videos have started to develop rapidly; Etc. At the same time, there are some problems existing in the advertising education of colleges and universities. For example, the goal of talent training is not in line with the needs of new media development; the curriculum structure fails to reflect the hot spots of the development of new media; there is overcorrection of the "attaching importance to theories but thinking little of practice"; the linkage with the advertising practical companies and institutions is not deep enough; etc. Under the condition that there is a gap between the development of media and advertising education, colleges and universities should reshape the concept of talent cultivation with new media characteristics combining with their own professional characteristics, and build a curriculum system with the courses of classical theories in communication and advertising as its foundation, courses of new media hot spots as the core, and platform courses as an extension; and cooperate with enterprises and institutions to cultivate compound advertising talents with high adaptability in the industry.

\section{REFERENCES}

[1] Du Fangwei: "On the Theory and Reality of McLuhan's 'Global Village'", Journal of Higher Education, 2015, Issue 17 (in Chinese)

[2] 199it: Penguin Intelligence: Report on 2017 New Media Trends in China, http://www.199it.com/archives/654084.html, November 16, 2017. (in Chinese)

[3] IFENG.COM: "The number of mobile Internet users in China has reached a new high, with the total number of 1.004 billion" https://finance.ifeng.com/a/20160928/14909822_0.shtml (in Chinese)

[4] China Business Industry Research Institute: "Data analysis of China's online game users in the first half of 2018: the number of mobile online game users reached 458 million"Http://www.askci.com/news/chanye/20180821/1740021129548. shtml. (in Chinese)

[5] China Business Industry Research Institute: "Data analysis of China's online video users in the first half of 2018: accounting for $76 \%$ of the total Internet users"Http://www.askci.com/news/chanye/20180821/1729491129543.sh tml. (in Chinese)

[6] Wang Ziwen, Yin Hong: "Investigation on Social Media Advertising Communication Strategy", A Vast View on Publishing, 2016, Issue 17. (in Chinese)

[7] Lin Shengdong: "The Six Trends of Future Advertising", Youth Journalist, the last issue in June 2016. (in Chinese) 